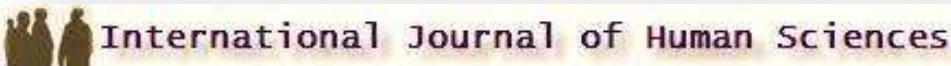

\section{Education as a prevention of fraud ${ }^{1}$}

\author{
Jiř́i Pospíšiil ${ }^{2}$ \\ Hana Vomáčková ${ }^{3}$
}

\begin{abstract}
A critical way of thinking developed by teachings of financial audit, accounting and taxation are necessary for any graduate in economics. Combined with ethics it is the essential prerequisite for increasing the resistance of the experts to embezzlement. The aim of this study is to ascertain whether the graduates of business schools in Czech Republic are ready to recognize and expose economic crime/fraud which they might encounter at their workplace. The readiness of the graduates is bilateral as it includes the ability "to recognize" which is discussed in terms of adequate knowledge - which should be obtained especially during the bachelor and master studies, and the willingness "to expose" which is discussed in terms of moral principles of the graduates - which should be augmented during their studies as well. The article summarizes the results of research conducted among Czech universities and their graduates. The research among the Czech universities was carried out as an analysis of the study programs provided by Czech universities and the corresponding syllabi. The research among the graduates was carried out via online questionnaire distributed to graduates through their alumni organizations. This questionnaire was accessible through the Internet from November 2014 to February 2015. During this period 264 respondents undertook the survey. We formulate two theses in this paper. First thesis states that Czech graduates are not equipped with knowledge necessary to recognize economic fraud at their workplace. Second thesis states that Czech graduates don't possess the moral incentives to expose the economic crime. While we were not able to confirm the first thesis unequivocally, we concluded that there is much to improve in the structure of the study programs of Czech universities providing business education. The second thesis was confirmed though. The suggestions we made in this paper based on the research were the following: firstly, to develop a syllabus of a new teaching subject which would incorporate the basic aspects of the advanced financial accounting, auditing, tax and business law and make such subject mandatory for all business graduates at Czech universities. Similar subject - even though less extensive/complex shall be developed for the secondary business schools as well. Secondly, to eliminate the segmented ethics of secondary school graduates through education based on case-studies and demonstration and focus greatly on raising the ethics standards at both levels of business education.

This paper is not a traditional field-based research study. Rather it is a summary/conclusive report on two interconnected research projects. The aim of this paper is to summarize the results from

\footnotetext{
1 This article is the well-developed form of paper which was presented at the 1st International Conference on Lifelong Education and Leadership for ALL - ICLEL 2015 which took place in Czech Republic on 29-31 October 2015.

2 Ph.D. student, University of Economics Prague, Faculty of Finance and Accounting, Department of financial accounting and auditing, Jiri.Pospisil@,vse.cz

${ }^{3}$ Prof., University of Economics Prague, Faculty of Finance and Accounting, Department of financial accounting and auditing, Hana.Vomackova@,vse.cz
} 
the former research projects and to compare andto confront the findings of these projects in the attempt to find a "common denominator" of both issues raised in the preceding research projects.

Keywords: fraud; education; accounting; financial reporting; ethics

\section{Introduction}

Economic crime and fraud is quite a frequent topic in Czech media lately. Almost every other week we learn about new cases of fraudulent behavior within the corporate world, local government even among the top politicians. The fact that economic crime is not a sparse phenomenon can be well documented for example by the statistics of the Police of the Czech Republic: although the number of crimes detected by the statistics of the Police Presidium oscillates around 9\%, their share of the total damage done by all the crimes accounts for more than two thirds. For example, in 2013 there were 30376 economic crimes committed and damage done by these actions reached a level of 19.5 billion CZK. In 2012 there were 27633 economic crimes in total worth of more than 24 billion CZK. The aim of this article is to answer the question of how the education - particularly higher education - can contribute to prevention and detection of fraud.

Let's focus on those offenses which can be detected by the employees of the financial department and advisory companies, i.e. in most cases the graduates of economic universities and business secondary schools. The most common offenses are: fraud, credit fraud and embezzlement. To a lesser extent tax evasion. Nevertheless according to the statistics of the Police Presidium of the Czech republic, the damages caused by tax evasion account for $20 \%$ of the damage caused by all the crimes together. Most costly economic crimes (in average) are: Fraud related to the Corporate Governance with an average damage of 9 mil. CZK per case, Tax Evasion with an average damage of 6 mil. CZK per case and Credit Fraud with average damage of 3 mil. CZK per case.

Based on the opinion that these economic crimes that cause the greatest damage could be detected early by competent personnel within the business corporations or cooperating consulting companies in the areas of taxation, accounting and finance, we formulate the following two theses: First thesis: Graduates of secondary business schools and university business schools are not equipped with such knowledge that would enable them to timely detect infringement occurring on their workplace. Second thesis: Graduates of secondary business schools and university business schools are not willing to take steps to thwart the infringement taking place within their workplace or to report such case in order to be properly investigated by competent authorities.

\section{Method}

To confirm or refute the above stated theses, we conducted research focused on two related areas: the research among the Czech universities was carried out as an analysis of the study programs provided by Czech universities and the corresponding syllabi - in order to find out whether the students of the economic programs receive the required theoretical and practical training - and also the research among the graduates which was carried out via questionnaires - in order to find out, what portion of the essential knowledge the graduates keep after they leave the education system. To determine the level of the graduates' ethics, we've applied the results of prior research of our colleagues and other researchers that concentrated on this topic.

The first part of the research was conducted as an analysis of the curricula of public and private universities offering education in the fields of study in economics (currently there are 38 educational institutions providing higher economic education in Czech Republic). Study programs of 16 public universities and 22 private universities were analyzed. The courses covering accounting, auditing, taxation, business law, corporate governance and business ethics were identified, the results were evaluated and compared to the findings of the survey among graduates in economic fields of study. This survey was conducted via an online questionnaire distributed to graduates through their alumni organizations. This questionnaire was accessible through the 
Internet from November 2014 to February 2015. During this period 264 respondents undertook the survey. The questionnaire consisted of ten questions aimed at finding: detailed information on their studies (private vs. public school, year of graduation, the list of courses taken), the level of basic competence gained from studying accounting (the approach of the multiple-choice question and the approach of the self-evaluation) and the degree of readiness of graduates in detecting economic crime in practice.

Before we proceed to discuss the various propositions, the basic characteristics of respondents who participated in the questionnaire survey should be mentioned. First of all, $84.8 \%$ of respondents graduated at public universities, while $25.4 \%$ of respondents graduated at private universities. Specialization in accounting, auditing \& taxes was indicated by $35.2 \%$ of respondents, specialization in financial management $21.6 \%$ of respondents, other fields of management $34.8 \%$ of respondents. The remaining $18.6 \%$ of respondents indicated specialization in banking, insurance and finance.

In the cases when the respondent have studied two fields simultaneously two specializations were indicated by the respondent. That results in total number of "studies" of 291, while the number of respondents was 264 . This fact makes the sum of percentages indicated above $110.2 \%$ instead of $100 \%$.

Table 1: The structure of respondents

\begin{tabular}{|l|c|c|}
\hline Question: What was your field of study? & Public school & Private school \\
\hline Financial management & 49 & 8 \\
\hline Other specialization in management & 61 & 31 \\
\hline Accounting & 47 & 26 \\
\hline Auditing & 8 & 0 \\
\hline Taxes & 12 & 0 \\
\hline Banking and Insurance & 47 & 2 \\
\hline
\end{tabular}

The second question of the questionnaire asked for the year of graduation. We found that $80 \%$ of respondents graduated between 2004 and 2014. Only 16\% of respondents indicated that their graduation falls between 1993 and 2003 and only 4\% of respondents graduated prior 1993.

\section{Findings}

In order for graduates of economic education programs to be able to take steps to thwart economic crime, they must first be able to recognize the signs of economic crime. This requires high-quality economic education, particularly in the areas of financial accounting, tax, commercial as well as civil law. Another important area is also corporate governance.

To confirm or refute the first thesis it is necessary to answer these two questions: 1) Are all graduates of economic education program required by the design of their study plan to undertake subjects covering the topics of financial accounting, reporting, taxation and law? 2) What is the quality of education in these subjects?

Economic education at the bachelor and master degree programs is offered by 38 educational institutions in total, out of which 16 are public universities and 22 are private educational institutions. While public universities offer a fairly balanced mix of economic subjects, private colleges focus primarily on the fields of management, international economic studies and financial management.

In accordance with our previous research (Pospíšil, 2014) and (Pospíšil, Polák 2014) we distinguish these subjects: Introduction to accounting, Advanced accounting, Standardization of financial reporting, Accounting for mergers \& acquisitions, Auditing, Corporate governance \& Ethics, Taxes \& Business law.

Our previous research (Pospísil, 2014) showed that even though there are 16 public universities offering education in the business and economics, only three of them cover all the necessary topics 
(accounting, IAS/IFRS, auditing, corporate governance, tax and business law). The situation is even worse in the private university sector. Private universities providing education in the economic field usually focus their education programs around general or specialized management, administration, territorial studies, etc. Studies concentrated on accountancy or auditing are less common at private universities. Introducing students to these fields is particularly important, regardless of specialty or focus of study program. Critical way of thinking developed by auditing and the knowledge of accounting and tax regulationare necessary for any graduate in the economic field. Along with the development of moral awareness and ethical standards it is the basic prerequisite for increasing the resistance of professionals in business against the fraudulent deeds.

Most often, the study programs are missing topics of accounting for mergers and acquisitions ${ }^{4}$, corporate governance and business ethics. Auditing is another topic which is often missing in the syllabi - some chapters are included in the lectures of advanced accounting. Only rarely universities offer a summarizing subject which would cover the key aspects of business law, tax and accounting. The relation among these areas are vitally important and leaving the linkage of the key topic to students is in our opinion very ineffective. Developing a broad subject which would incorporate crucial topics from tax, accounting, corporate governance and auditing would be utmost beneficial for all graduates of economic schools on both levels: universities and secondary schools.

Table 2: Incidence of the relevant subjects in the respondents' study plans

\begin{tabular}{|l|c|}
\hline Question: Which courses did you take during your studies? & \% respondents \\
\hline Introduction to accounting & $92,3 \%$ \\
\hline Advanced accounting & $66,0 \%$ \\
\hline Financial reporting and consolidation of financial reports & $32,4 \%$ \\
\hline Auditing & $30,5 \%$ \\
\hline Standardization of financial reporting & $31,3 \%$ \\
\hline Tax \& Business law & $64,5 \%$ \\
\hline Mergers \& Acquisitions & $22,0 \%$ \\
\hline Ethics in business & $18,1 \%$ \\
\hline Corporate governance & $7,7 \%$ \\
\hline Business valuation & $42,9 \%$ \\
\hline
\end{tabular}

Introduction to accounting undertook $92.3 \%$ of respondents. Although rather high number, circa $8 \%$ - although graduates of business schools - did not pass even basic accounting courses, which we believe to be a considerable problem. These $8 \%$ consist of graduates of management other than financial management.

Relatively well-spread were classes of Advanced accounting and Tax \& Business law. Other subjects are covered to a lesser extent. Unfortunately, the low coverage of the Corporate governance and Ethics in business indicated above was confirmed. These classes are crucial for building resilience of the graduates against economic crime, especially in the fields of management, for which this area should be a compulsory part of the curriculum.

We can conclude that universities offering business education have built up the range of essential classes, the fundamental problem however is the fact that these classes are not mandatory for all students of business and economics. There are some business schools providing economic education which are missing some of these classes entirely. It is necessary to concentrate more on business ethics and corporate governance which are missing in graduates' portfolio very often. The solution to this problem would be in our opinion a compulsory subject which would contain the basics from various disciplines with an emphasis on training students in the ways of detection of

${ }^{4}$ An interesting comparison of the education of accounting for mergers and acquisitions between Czech Republic and Slovakia was published by Ašenbrenerová (2014). 
financial fraud and its prevention. An equivalent of such class should be then adopted (with some adjustments) to the curriculum of secondary economic schools specializing in economics.

The research continued with the survey among the graduates aiming to find out, what portion of knowledge they have been keeping after they left the university. The questionnaire confronted the graduates with two types of questions: multiple-choice questions asking for the basic concepts of the financial accounting and financial audit and auto-evaluation questions asking for their opinion on the quality of education they received and their own readiness to expose the economic crime. The findings steaming from the questionnaire were ambiguous and unfortunately did not help to confirm nor refute the first thesis. The research showed that there is much to improve in the constitution of the economic study programs though. The study programs and the syllabi of the subjects needs to be improved in terms of both: scope and quality. The scope of the subjects needs to be adjusted in the way that every graduate of economic program is required to undertake a basics of financial accounting, auditing, tax, corporate governance and business law as well as business ethics. The quality of the education should be improved in terms of interconnecting these topics into homogenous unit and show the students the linkage among them as well as potential pitfalls. In other words, the knowledge of this topics needs to be passed on in a form that will ensure not only understanding of the general theoretical concept, but also allows to apply the knowledge to actual cases in which the graduates encounter at their workplace. These adjustments are desirable not only for universities, but in lesser extent for secondary business school as well - as elaborated by Berková (2014) or Berková, Polák (2014).

The quality knowledge is certainly very important aspect, because it allows to detect the fraud. Nevertheless to deal with the second thesis, we need to take a closer look at the other aspect, i.e. the ethical standards of the graduates and their determination to act. It is the better judgment of the employees that stimulate them to take an action and to thwart the actions which are contrary to the social rules and conventions or laws. It follows that one of the priorities for higher education as well as the secondary school education must be apart from the transfer of knowledge and experience, building a strong moral and ethical standards, which in the longer term results in improving the overall ethical climate in society that will form a very effective barrier for perpetrators of economic crimes. To confirm or refute the second thesis we adopted the existing research that has been already done on this topic. There are several studies dealing with the level of ethics of students of secondary business schools and universities. The most recent and relevant for my research are the ones of Kaliská, Kaliský (2014) and Kučerová (2007).

Kaliská, Kaliský (2014) based their research on Defining Issue Test ("DIT") which was designed by Rest (1979) using Kohlberg theory. This testing instrument had been used many times before in research of for example Gielen (1996), Shafto, Deinse (1977) or Moon (1986). The results of their research showed, that the level of ethical development of students is influenced greatly by their age and education. This research thus shows direct interconnection between education and level of moral development.

The aim of Kaliská, Kaliský (2014) study was to answer four questions. The first question of their research is the most relevant for this paper - the question stands: What is the level of ethics according to DIT? The research of Kaliská, Kaliský (2014) showed that $95 \%$ of students tested belongs to the "conventional level" of ethical development. Approximately $5 \%$ of students tested belongs to the "post-conventional level" of ethical development. These findings are in line with former research of Rest (1979) who conducted the same testing procedure on university graduates. Kaliská, Kaliský explain the problem of current education system at secondary school as the lack of systematic education of ethics through dilemma-solving case studies: 
Pospíšil, J., \& Vomáčková, H. (2016). Education as a prevention of fraud. International Journal of Human Sciences, 13(1), 1133-1140. doi:10.14687/ijhs.v13i1.3638

"Do relativne nį̧keho počtu žiakov zastúpených v postkonvenčnej úrovni vstupovalo niekollko premenných. Žiaci stredných škôl nie sú v našom školskom systéme cielene konfrontovani s riešenim situácii s morálnym konfliketom v podobe morálnej dilemy, a tak test DIT1 pozostávajúci zo šiestich morálnych dilem mobol byt' pre nich náročny." (Kaliská, Kaliský, 2014, p. 401)

The lack of education in ethics at secondary schools is not made up at universities either - as showed in text above the business ethics is very often missing in the study programs of most universities. Moreover - great deal of graduates of secondary school will not continue their studies on the universities, which means that the lack of ethics education cannot be fixed afterwards. And this is the reason why it is necessary to start with the systematic education of ethics no later than at secondary schools.

Another research pointing out the unsatisfying level of ethics development by graduates of secondary business schools was conducted by Kučerová (2007). Kučerová arranged a research among 224 students of two secondary business schools in June 2006. The research was conducted as a case-study with follow-up questionnaire. The questionnaire consisted of six segments out of which three segments focused on students' ethics development when assessing dilemma in their personal/family life while the other three segments were focused on dilemma at the school/workplace and business area.

The research of Kučerová concluded into three related findings. First of all, Kučerová identified segmented ethics in her research which means that students apply different set of standards when dealing with dilemma in their personal life and different set of standards when dealing with the dilemma in the professional life.

"Provedený výzkum dokáaral, že u studentu obchodnich akademii se objevije existence təov. segmentované morálky, tj. studenti uvažuji o morálních dilematech profesního (ekonomickébo) prostredi na jiné úrovni morálníbo usuzováni než. je tomu u morálnich dilemat rodinného prostrèdí." (Kučerová, 2007)

Secondly, Kučerová found that when dealing with dilemma in professional life, students apply less developed ethical standards. In terms of Heidbrink, when students deal with work-related dilemma they show ethical development of third level but when they deal with personal-life related dilemma, they show ethical development of fourth level (i.e. more developed ethical standards).

"Vètšina studentũ obchodnich akademií, pokud jde o usuqováni nad profesnimi morálnimi dilematy, se nachází na tretím stupni morálního usuzováni, kede blavnim motivem rozhodováni je dosaženi shody s ostatnimi ve smyslu vytvárení pozitivnich vztabĩ a vytvoreni dojmu být „dobry" manažer, vedoucí, kolega, zaměstnanec apod. Naopaku morálnich dilemat rodinného a prátelského prostredí se vétšina studentu nachází na čturtém stupni morálního usuzováni, kede blavnim motivem usuzováni a rozhodováni je respektováni zákona a spolě̀enského porádku." (Kučerová, 2007)

Lastly, Kučerová found that the level of ethical standards applied by the students is changing in time as the students in their first and second year show less developed ethical standards then students in their third of fourth year of secondary education. Kučerová thus concludes that the education contributes to ethical standards improvement.

"Dále bylo ověreno, že vývojový stupeñ morálního usuzováni studentui prvnich ročníkù obchodnich akademií je nǐ̌šri než vývojový stupen studentu čturtých ročníki a že s ristem věku jedince roste $i$ stupeň morálního usuzováni danébo jedince." (Kučerová, 2007)

We believe that the results of the above described research of Kaliský, Kaliská (2014) and Kučerová (2007) confirm the second thesis I have formulated at the beginning of this article. 


\section{Conclusion}

This paper aimed to determine whether the graduates of the economics are ready to face the economic crime which they might encounter at their workplace. At the beginning of the article we set out two theses. The survey conducted among graduates of business universities showed that only a fraction of the graduates leaves the education system equipped with sufficient knowledge and experience to detect the fraudulent activities that occur in the financial accounting and financial reporting. The research shows, there are many graduates of business schools who misunderstand the aim of financial accounting and the reason for financial reports and auditing. The misinterpretation of the key outcomes of financial accounting by some respondents is a strong incentive for further discussion regarding the structure of study programs and subjects syllabi of all economic-related studies as well as regarding the means of lecturing the accounting and tax related subjects.

We believe it is absolutely essential for each graduate of economically oriented study programs to undergo at least a basic course in financial accounting. This course cannot be taught as a bookkeeping course. It needs to be aimed at proper understanding and interpretation of the financial statements and other important information financial accounting provides altogether with a thorough understanding of the assumptions which the accounting as a model is limited by. All students of economic programs, should also undergo general subject introducing students to the basic aspects of corporate governance, financial audit and business law. Last but not least, there should be business ethics incorporated into the curriculum as a mandatory subject. Important task is to design such course as case-study and dilemma solving discussions rather than theoretical lectures. It would require experienced lectures with rich business background who has got plenty experience in this area to pass on the students.

This approach needs to be transferred in a modified form also to secondary business schools. Especially in the third or fourth year of their studies, students of secondary business schools should divert in their understanding of accounting as a routine book-keeping and begin to look at the financial accounting as a comprehensive system and its final outcome - the financial statements. Education in ethics is also much needed at secondary schools - perhaps even more than in the case of universities, because there are many students who don't continue their studies after they finish the secondary school and leave for work thus further education in this areas is not possible. Besides a long-term education only will make sure that the moral standard will improve and the segmented morale will be eliminated.

Thus conceived, targeted interaction with the professional and moral readiness of graduates in economic fields consider the best possible tool for fighting economic crime, because it helps to prevent and liquidate it in its beginning. Critical way of thinking developed by discipline accounting audit and accounting knowledge and related legislation should be a necessary accessory for any graduate of business and economics. Along with the development of moral awareness and ethical behavior is the basic prerequisite for increasing the resistance against the misappropriation of economic experts.

\section{References}

Ašenbrenerová, P. (2014) Komparace vądèlávacich systémi v oblasti konsolidované účetní qávèrky v Céské a Slovenské republice. Hradec Králové: Interdisciplinární mezinárodní vědecká konference doktorandů a odborných asistentů QUAERE 2014, 856-862

Berková, K. (2014). Hodnoceni výsledkì vædèláváni žákư obchodnich akademii ve vætabu ke studiu IFRS: empirická studie. Český finanční a účetní časopis. 4, 133-148.

Berková, K., Polák, M. (2014). Začlenèní problematiky bospodárškých a majetkových trestných činu v danovém a účetním kontextu v kurikulu sekundárníbo vądèlávání. Český finanční a účetní časopis. 3, 132 149. 
Gielen, U. P. (1996). Moral reasoning in cross-cultural perspective: a review of Koblbergian research. World Psychology. 2 (4), 313-333.

Kaliská, L., Kaliský J. (2014) Morálne usudzovanie merané testom DIT u stredoškolákov (vo vątabu k poblaviu, veku a vierovyznaniu). Pedagogika. 64 (4): 393-406.

Kučerová, M. (2007). Edukace v morálni oblasti. Český finanční a účetní časopis. 2 (1.), 48-60.

Martin, R. M., Shafto, M., Van Deinse, W. (1977). The reliability, validity, and design of the Defining Issues Test. Developmental Psychology. 13(5), 460-468.

Moon, Y. (1986). A review of cross-cultural studies on moral judgment development using the Defining Issues Test. Behavior Science Research, 20 (4), 147-177.

Pospísili, J. (2014). Výnka pokročilého úcetnictví a finančního auditu na českéch vysokých školách. The 15th Annual Conference of the Faculty of Finance and Accounting. 15, 40-55.

Pospíšil, J., Polák M. (2014) Priq̨kum výsledkư výuky účetnictví na VŠE v Praz̨e. MMK 2014 Mezinárodní Masarykova konference pro doktorandy a mladé vědecké pracovníky. 14391447.

Rest, J. (1979). Development in Judging Moral Issues. Minneapolis: University of Minnesota Press. 